\title{
Effect of Humic Acid, Mycorrhiza Inoculation, and Biochar on Yield and Water Use Efficiency of Flax under Newly Reclaimed Sandy Soil
}

\author{
Bakry Ahmed Bakry1, Omar Maghawry Ibrahim², Abdelraouf Ramadan Eid³, \\ Elham Abdelmoneim Badr ${ }^{1}$ \\ ${ }^{1}$ Field Crops Research Department, National Research Centre, Dokki, Egypt \\ ${ }^{2}$ Plant Production Department, Arid Lands Cultivation Research Institute, City of Scientific Research and \\ Technological Applications (SRTA-City), New Borg El-Arab, Egypt \\ ${ }^{3}$ Water Relations and Field Irrigation Department, National Research Center, Giza, Egypt \\ Email: Bakry ahmed2004@yahoo.com
}

Received 29 September 2014; revised 13 October 2014; accepted 14 November 2014

Copyright (C) 2014 by authors and Scientific Research Publishing Inc.

This work is licensed under the Creative Commons Attribution International License (CC BY).

http://creativecommons.org/licenses/by/4.0/

(c) (†) Open Access

\begin{abstract}
In order to examine the application of different soil and foliar organic fertilizers as well as biofertilizing flax under sandy soil conditions, two field experiments were carried out at the Research and Production Station of the National Research Centre (NRC), Al Nubaria district, El-Behaira Governorate, Egypt during 2012/2013 and 2013/2014 winter seasons. The trials aimed to study the effect of humic acid (HA) as low cost natural fertilizer, inoculation with mycorrhiza, and biocharcoal on on yield, quality and water use efficiency of flax variety (Amon) under newly reclaimed sandy soil. The treatments consisted of HA $(25 \mathrm{~kg} /$ feddan), inoculation with mycorrhiza $(1 \mathrm{~kg} /$ feddan), and biochar ( 4 tons/feddan) and all the combinations among the treatments. Results showed that the treatment combination of (humic acid + mycorrhiza + biochar) was significantly superior compared to all the other treatments in number of capsules/plant, biological yield/plant (g), seed yield/plant (g), seed yield (kg/feddan), straw yield (tons/feddan), oil percent (\%), and oil yield (kg/feddan). However, it gave the highest fruiting zone length $(\mathrm{cm})$ but not significantly different from (mycorrhiza + biochar) and (humic acid + biochar), also it gave the highest seed index (g) but not significantly different from humic acid and (humic acid + mycorrhiza). The treatment combination of (humic acid + biochar) gave the highest plant height $(\mathrm{cm})$, technical stem length (cm), and number of branches/plant.
\end{abstract}




\section{Keywords}

\section{Flax, Humic Acid, Biochar, Mycorrhiza, Water Use Efficiency}

\section{Introduction}

Flax was already grown 6000 - 8000 years ago in Egypt together with barley and wheat [1]. Flax plays an important role in the national economy owing to export beside local industry. Flax is considered one of the most important dual purpose crops for oil and fiber production in Egypt and the world [2] flax is rich in oil (41\%), protein (20\%), and dietary fiber (28\%). Also it has high percentage of essential fatty acids.

The mycorrhiza fungi can be benefit to plants by enhancing the availability of soil water and nutrients [3]. The inoculation may improve crop yield by increasing the capacity of plant to obtain nutrients that are relatively immobile in the soil such as phosphorus [4] [5]. Humic acid is an organically charged bio-stimulant that significantly affects plant growth and development and increase crop yield. It has been extensively investigated [6]. Humic acid improves physical [7], chemical and biological properties of soil [8] [9]. The role of humic acid is well known in controlling soil borne diseases and improving soil health and nutrients uptake by plants, and increasing mineral availability [10].

Charcoals are produced annually for cooking and industrial purposes. Most of this production is located in developing countries rather than developed countries. Charcoal production is often detrimental to the environment, as it leads to deforestation and air pollution. Yet, most developing countries have few alternatives to charcoal production for household fuel. However, significant improvements are possible with viable alternatives as far as wood production, charcoal production with respect to human health and use of charcoal waste is concerned. Additionally, it has been argued that use of charcoal as a fuel replacing wood leads to lower levels of household indoor pollution and an associated reduction in mortality [11]. Charcoal waste can be applied as biochar to agricultural soils (including the fields where the trees are grown for charcoal production) and turned into a valuable resource for improving crop yields on acid and infertile soils where nutrient resources are scarce [12]. Biochar can act as a soil conditioner enhancing plant growth by supplying and, more importantly, retaining nutrients and by providing other services such as improving soil physical and biological properties [12].

\section{Materials and Methods}

Two field experiments were carried out at the Research and Production Station of the National Research Centre (NRC), Al Nubaria district, El-Behaira Governorate, Egypt during 2012/2013 and 2013/2014 winter seasons to study the effect of humic acid (HA), inoculation with mycorrhiza, and biochar (charcoal or biomass-derived black carbon) on seed yield, yield components and water use efficiency of flax variety (Amon) under newly reclaimed sandy soil. Physical and chemical properties of the soil (Table 1) were analyzed according to [13].

The experimental design was Complete Randomized Block Design. Plot area was $10.5 \mathrm{~m}^{2}$ (3.5 m long and 3 $\mathrm{m}$ wide). Phosphorus fertilizer was added before sowing at the rate of $31 \mathrm{~kg}_{2} \mathrm{O}_{5} /$ feddan as calcium superphosphate $\left(15.5 \% \mathrm{P}_{2} \mathrm{O}_{5}\right)$ while potassium was added at the rate of $24 \mathrm{~kg} \mathrm{~K} / \mathrm{feddan}$ as potassium sulphate (48\% $\mathrm{K}_{2} \mathrm{SO}_{4}$ ), nitrogen fertilizer was applied at the rate of $75 \mathrm{Kg} \mathrm{N} /$ feddan in the form of ammonium nitrate (33.5\% N) in three equal portions, 20 days after sowing, before second irrigation, and at the flowering stage. Sowing was in mid-November in both seasons. The treatments were as follow: Control, mycorrhiza (1 kg/feddan), biochar (4 tons/feddan), humic acid (25 kg/feddan), (humic acid + mycorrhiza), (humic acid + biochar), (mycorrhiza + biochar), and (humic acid + mycorrhiza + biochar). Irrigation was carried out using sprinkler irrigation system where water was added every 5 days.

Flax plants were pulled at full maturity, and then left on ground for air-drying. Capsules were removed carefully. At harvest the following characters were recorded on a random sample of ten guarded plants from each

Table 1. Physical and chemical analyses of soil.

\begin{tabular}{cccccccccccc}
\hline Sand, \% & Silt, \% & Clay, \% & Soil texture & pH & E.C. dS/m & CaCO $_{3}$ & O.M.\% & N, ppm & P, ppm & K, ppm \\
\hline 93.7 & 3.9 & 4.78 & sandy & 7.8 & 0.5 & 1.6 & 0.24 & 9.2 & 3.6 & 23.5 \\
\hline
\end{tabular}


plot: Plant height $(\mathrm{cm})$, Fruiting zone length $(\mathrm{cm})$, Technical stem length $(\mathrm{cm})$, Number of fruiting branches/ plant, Number of capsules/plant, Seed yield/plant (g), Biological yield (g/plant), Seed yield (g/plant), Seed index, Seed yield (kg/fed), Straw yield (tons/fed).

Water use efficiency (WUE): Was calculated according to [14] as follows: WUE $\left(\mathrm{kg}_{\text {grain }} / \mathrm{m}^{3}\right.$ water $)=$ Total yield, (kg/fed/season)/Total applied irrigation water $\left(\mathrm{m}^{3}\right.$ water $\left./ \mathrm{fed} / \mathrm{season}\right)$.

Oil yield ( $\mathrm{kg} / \mathrm{fed})$ was calculated by Seed yield $(\mathrm{kg} / \mathrm{fed}) *$ Seed oil $(\%)$.

Seed oil \%: was determined by Soxhlet apparatus using petroleum ether $\left(40^{\circ} \mathrm{C}-60^{\circ} \mathrm{C} \mathrm{b.p}\right)$ according to the Official Method [15]. Oil yield (kg/fed) was calculated by Seed yield (kg/fed) * Seed oil (\%). The obtained results were subjected to statistical analysis of variance according to method described by [16] since the trend was similar in both seasons the homogeneity test Bartlet's equation was applied and the combined analysis of the two seasons was calculated according to the method [17].

\section{Results and Discussion}

The results presented in Table 2 indicated that the treatment (humic acid + mycorrhiza + biochar) significantly affected all the studied characteristics and surpassed all the other treatments especially in seed yield (509.97 $\mathrm{kg} / \mathrm{feddan}$ ) and oil yield (199.45 kg/feddan). These results may be due to the highest obtained values of fruiting zone length $(21 \mathrm{~cm})$, number of capsules/plant (17), biological yield/plant $(1.57 \mathrm{~g})$, seed yield/plant $(0.19 \mathrm{~g})$, seed index (6.00 g), and seed oil (39.11\%) under that treatment. In addition, the results indicated that the treatment also gave the highest straw yield (2.52 tons/feddan) as compared to the other treatments.

Diversity of organisms interacting with biochar

Data presented in Table 2 clearly showed that all combined applications of Mycorrhiza, Biochar and Humic acid appeared greater and significant effects on all studied characters except technical length, No. of branches/ plant, straw yield and oil percentage characters when the plants treated with the combination Mycorrhiza + Biochar. The data showed yield increases ranged between (48.6\%) when the single treatments applied, while such increase ranged between (65.4\% - 169.3\%) with the different combination compared to the control. Either biochar or humic acid applications were more efficient than mycorrhiza under single or combined applications. The lower response of mycorrhiza than other treatments in single or combined application could be attributed to the activity of mycorrhizae which is sensitive to management interventions, such as adding biochar, and it is tempting to speculate on the possible synergistic effects of mycorrhizal inoculation and biochar application in enhancing soil quality and plant growth. Also, applying biochar to soil stimulated the colonization of crops by Arbuscular Mycorrhiza (AM) fungi. [18] reported that root infection by Arbuscular Mycorrhiza (AM) fungi significantly increased alfalfa yield by 40 to 80 percent

Table 2. Effect of humic acid, mycorrhiza, biochar, and interactions among them on flax yield and its components, water use efficiency and oil \% in flax seeds. Combined of 2012/2013 and 2013/2014 seasons.

\begin{tabular}{|c|c|c|c|c|c|c|c|c|c|}
\hline & Control & Mycorrhiza & Biochar & $\begin{array}{l}\text { Humic } \\
\text { Acid }\end{array}$ & $\begin{array}{l}\text { Mycorrhiza } \\
+ \text { Biochar }\end{array}$ & $\begin{array}{l}\text { Humic Acid + } \\
\text { Biochar }\end{array}$ & $\begin{array}{c}\text { Mycorrhiza + } \\
\text { Humic Acid }\end{array}$ & $\begin{array}{c}\text { Mycorrhiza + } \\
\text { Humic Acid + } \\
\text { Biochar }\end{array}$ & $\mathrm{LSD}_{0.05}$ \\
\hline Plant height, $\mathrm{cm}$ & 53.67 & 53.33 & 69.00 & 70.67 & 69.67 & 82.00 & 81.33 & 80.00 & 3.51 \\
\hline Fruiting zone length, cm & 12.67 & 10.67 & 13.67 & 16.67 & 20.33 & 20.67 & 16.33 & 21.00 & 2.12 \\
\hline Technical stem length, cm & 41.00 & 42.67 & 55.33 & 54.00 & 49.33 & 61.33 & 65.00 & 59.00 & 1.88 \\
\hline Number of branches/plant & 3.33 & 3.67 & 4.67 & 4.67 & 3.33 & 7.33 & 6.00 & 6.33 & 0.13 \\
\hline Number of capsules/plant & 7.00 & 6.67 & 8.00 & 13.67 & 9.33 & 13.33 & 15.33 & 17.00 & 0.23 \\
\hline Biological yield/plant, g & 0.84 & 1.12 & 1.29 & 1.24 & 1.22 & 1.51 & 1.39 & 1.57 & 0.03 \\
\hline Seed yield/plant, g & 0.10 & 0.13 & 0.12 & 0.14 & 0.14 & 0.16 & 0.15 & 0.19 & 0.01 \\
\hline Seed index, g & 4.10 & 4.33 & 4.61 & 5.95 & 5.32 & 5.83 & 5.97 & 6.00 & 0.21 \\
\hline Straw yield, tons/feddan & 0.95 & 1.30 & 1.73 & 1.82 & 1.55 & 1.74 & 2.08 & 2.52 & 0.11 \\
\hline Seed yield, kg/feddan & 189.33 & 281.25 & 305.19 & 435.27 & 313.18 & 457.15 & 393.97 & 509.97 & 25.50 \\
\hline Relative yield, \% & - & 48.6 & 61.2 & 129.9 & 65.4 & 141.5 & 108.1 & 169.3 & \\
\hline $\begin{array}{l}\text { Water use efficiency of } \\
\text { flaxseed, } \mathrm{kg} / \mathrm{m}^{3}\end{array}$ & 0.092 & 0.137 & 0.149 & 0.212 & 0.153 & 0.223 & 0.192 & 0.249 & 0.02 \\
\hline Seed oil, \% & 36.33 & 37.15 & 36.81 & 38.17 & 36.56 & 38.33 & 37.53 & 39.11 & 0.27 \\
\hline Oil yield, kg/feddan & 68.78 & 104.48 & 112.34 & 173.01 & 114.50 & 175.23 & 147.86 & 199.45 & 4.33 \\
\hline
\end{tabular}


when $1 \mathrm{~kg} / \mathrm{m}^{2}$ of biochar was added to an alfalfa field in a volcanic ash soil.

From the same table it is clear that the efficiency of application of biochar combined with the other two treatments may be attributed that it be used as a soil amendment to improve soil quality and to increase crop production, this will increase its appeal. In this regard, an obvious positive attribute of biochar is its nutrient value, supplied either directly by providing nutrients to plants or indirectly by improving soil quality, with consequent improvement in the efficiency of fertilizer use. As a measure of the direct nutrient value of biochar, it is not the total content but, rather, the availability of the nutrient that is an important consideration. Moreover, the indirect nutrient value of biochar is its ability to retain nutrients in the soil and, therefore, to reduce leaching losses, resulting in increased nutrient uptake by plants and higher production. According to [19] the indirect nutrient value of biochar is the removal of soil constraints limiting plant growth and production (e.g. the use of lime to overcome soil acidity, with resulting improvement in fertilizer-use efficiency and increases in plant production).

The obtained results are in agreement with [20]. The highest values obtained from that treatment may be due to the improvement of soil conditions and the establishing equilibrium among plant nutrients which considered important for soil productivity and plant production where some investigators, [21] revealed that humic acid substance and mycorrhiza inoculation lead to the improvement of soil and increased the yield of some field crops. Also, mycorrhiza fungi play an important role in the whole plant nutrients balance by aiding in the uptake of limiting nutrients and maintaining the nutrients.

Also, the results from the current study agree with [22] who reported positive response to biochar in combination with fertilizer in pot trials, and [23] who stated that maize and peanut yields were enhanced where bark charcoal was applied in combination with $\mathrm{N}$ fertilizer in the field.

As shown in Figure 1, the increase in seed yield, kg/feddan when the treatment (humic acid + mycorrhiza + biochar) was adopted was $29.44 \%, 11.55 \%, 62.84 \%, 17.16 \%, 67.10 \%, 81.32 \%, 169.36 \%$ as compared to (humic acid + mycorrhiza), (humic acid + biochar), (mycorrhiza + biochar), humic acid, biochar, mycorrhiza, and control, respectively.

These results are in accordance with those obtained by [24] who reported positive yield effects from biochar addition and were able to establish that the impact were in part due to non-nutrient improvement to soil functioning.

\section{Correlation Coefficient}

Table 3 showed the correlation coefficient among the studied characters of flax variety (Amon). As shown in the table, there was a highly positive significant simple correlation coefficient among all the studied characters at $5 \%$ level of significance.

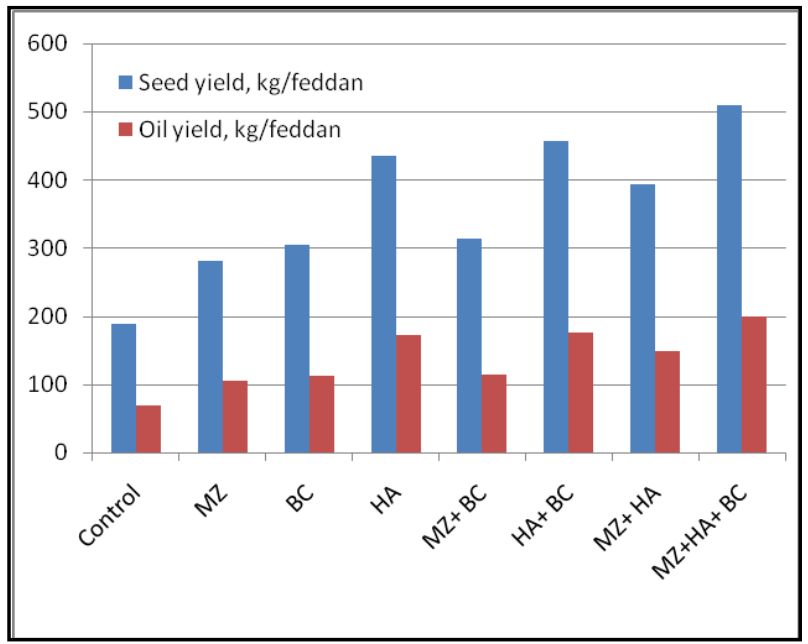

Figure 1. Seed yield of flax variety (Amon) as affected by the studied treatments. $\mathrm{MZ}=$ Mycorrhiza, $\mathrm{BC}=$ Biochar, $\mathrm{HA}=$ Humic Acid. 
Table 3. Correlation coefficient of the agronomic characters of flax variety (Amon) as affected by the studied treatments.

\begin{tabular}{|c|c|c|c|c|c|c|c|c|c|c|c|c|}
\hline & $\times 1$ & $\times 2$ & $\times 3$ & $\times 4$ & $\times 5$ & $\times 6$ & $\times 7$ & $\times 8$ & $\times 9$ & $\times 10$ & $\times 11$ & $\times 12$ \\
\hline$\times 1$ & 1 & & & & & & & & & & & \\
\hline$\times 2$ & 0.804 & 1 & & & & & & & & & & \\
\hline$\times 3$ & 0.962 & 0.612 & 1 & & & & & & & & & \\
\hline$\times 4$ & 0.855 & 0.584 & 0.870 & 1 & & & & & & & & \\
\hline$\times 5$ & 0.868 & 0.712 & 0.829 & 0.789 & 1 & & & & & & & \\
\hline$\times 6$ & 0.904 & 0.721 & 0.873 & 0.861 & 0.798 & 1 & & & & & & \\
\hline$\times 7$ & 0.783 & 0.772 & 0.689 & 0.745 & 0.857 & 0.901 & 1 & & & & & \\
\hline$\times 8$ & 0.901 & 0.797 & 0.833 & 0.725 & 0.940 & 0.808 & 0.822 & 1 & & & & \\
\hline$\times 9$ & 0.841 & 0.637 & 0.827 & 0.715 & 0.886 & 0.897 & 0.881 & 0.825 & 1 & & & \\
\hline$\times 10$ & 0.852 & 0.740 & 0.795 & 0.826 & 0.914 & 0.910 & 0.920 & 0.916 & 0.887 & 1 & & \\
\hline$\times 11$ & 0.679 & 0.586 & 0.635 & 0.797 & 0.856 & 0.801 & 0.883 & 0.777 & 0.802 & 0.945 & 1 & \\
\hline$\times 12$ & 0.826 & 0.722 & 0.768 & 0.809 & 0.913 & 0.884 & 0.907 & 0.909 & 0.874 & 0.998 & 0.956 & 1 \\
\hline
\end{tabular}

$\times 1=$ Plant height, $\mathrm{cm} ; \times 2=$ Fruiting zone length, $\mathrm{cm} ; \times 3=$ Technical stem length, $\mathrm{cm} ; \times 4=$ Number of branches $/$ plant; $\times 5=$ Number of capsules/plant; $\times 6=$ Biological yield $/$ plant (g); $\times 7$ = Seed yield $/$ plant (g); $\times 8=$ Seed index (g); $\times 9=$ Straw yield, tons/feddan; $\times 10=$ Seed yield, $\mathrm{kg} /$ feddan; $\times 11=$ Seed oil, \%; $\times 12$ = Oil yield $(\mathrm{kg} /$ feddan).

\section{Conclusion}

The current study is strongly indicating the importance of the included organic resources in improving the productivity and quality of flax crop. The results directly confirm the role of humic acid, mycorrhiza, and biochar in fertile the soil and building the organic carbon which may help in improving soil quality of the sandy soils and increasing the water holding capacity and consequently increasing yield and productivity.

\section{References}

[1] Zohary, D. and Hopf, M. (2000) Domestication of Plant in the Old World. The Origin and Spread of Cultivated Plants in West Asia, Europe and Nile Valley. Oxford University Press, Oxford, 316.

[2] El-Hariri, D.M., Bakry, A.B., Elewa, T.A. and Ibrahim, O.M. (2012) Evaluation of Some Flax (Linum usitatissimum L.) Varieties under the Conditions of Newly Reclaimed Sandy Soils. International Journal of Academic Research, 4, 98102.

[3] Smith, S.E. and Read, D.J. (1997) Mycorrhiza Symbiosis. 2nd Edition, Academic Press, London, 605.

[4] Rhodes, L.H. (1980) The Use of Mycorrhiza in Crop Production. System outlook Agric., 10, 275-281.

[5] Jansa, J., Mazafar, A., Kuhum, G., Anken, T. and Frossard, E. (2003) Soil Tillage Affect the Community Structure of Mycorrhiza Fungi in Maize Root. Ecological Applications, 13, 1164-1176. http://dx.doi.org/10.1890/1051-0761(2003)13[1164:STATCS]2.0.CO;2

[6] Nardi, S.D., Zzeghello, P. and Pandalai, S.G. (2004) Rhizoshere a Communication between Plant and Soil. Recent Research Development in Crop Science, 1, 349-360.

[7] Varanimi, Z., Pinton, R., Behnke, H.D., Esser, U., Kadereit, J.W. and Ringe, M. (1995) Humic Substances and Plant Nutrition. Progress in Structural Botany, Physiology, Genetics, and Taxonomy. Geobotany, 56, 97-117.

[8] Keeling, A.A., McCallum, K.R. and Bekwith, C.P. (2003) Crop and Environment Research Center, Harper Adans University College, Newport, Shropshire, UK. Bioresource Technology, 90, 127-137.

[9] Mikkelson, R.L. (2005) Humic Materials for Agriculture, Davis, California, USA. Better Crops with Plant Food. Better Crops with Plant Food, 89, 6-7.

[10] Mouromical, G.M., Angela, G.L. and Monaco, A.L. (2011) The Effect of Organic Supplementation of Solarized Soil on the Quality of Tomato. Scientific Horticulture, 129, 189-196. http://dx.doi.org/10.1016/j.scienta.2011.03.024

[11] Bailis, R., Ezzati, M. and Kammen, D.M. (2005) Mortality and Greenhouse Gas Impacts of Biomass and Petroleum Energy Futures in Africa. Science, 308, 98-103. http://dx.doi.org/10.1126/science.1106881

[12] Lehmann, J. and Rondon, M. (2005) Biochar Soil Management on Highly-Weathered Soils in the Humid Tropics. In: Uphoff, N., Ed., Biological Approaches to Sustainable Soil Systems, CRC Press, Boca Raton, 517-529.

[13] Page, A.L., Miller, R.H. and Keeney, D.R. (1982) Methods of Soil Analysis: Part 2 Chemical and Microbiological Properties. ASA Inc., SSSA, Inc., Medisio Wiscansin. 
[14] Stanhill, G. (1986) Water Use Efficiency. Advances in Agronomy, 39, 53-85. http://dx.doi.org/10.1016/S0065-2113(08)60465-4

[15] Unknown Author (1970) Official Methods of the Association of Official Analytical Chemists. 11th Edition, Association of Official Analytical Chemists, Washington DC.

[16] Snedecor, G.W. and Cochran, W.G. (1982) Statistical Method. 7th Edition, Iowa State University Press, Ames.

[17] Gomez, K.A. and Gomez, A.A. (1984) Statiscal Procedures for Agriculture Research. 2nd Edition, John Wily and Sons, New York.

[18] Nishio, M. and Okano, S. (1991) Stimulation of the Growth of Alfalfa and Infection of Mycorrhizal Fungi by the Application of Charcoal. National Grassland Research Institute, 45, 61-71.

[19] Glaser, B., Lehmann, J. and Zech, W. (2002) Ameliorating Physical and Chemical Properties of Highly Weathered Soils in the Tropics with Charcoal: A Review. Biology and Fertility of Soils, 35, 219-230. http://dx.doi.org/10.1007/s00374-002-0466-4

[20] Khalifa, R.K.M., Manal, F.M., Bakry, B.A. and Zeidan, M.S. (2011) Response of Some Flax Varieties to Micronutrients Foliar Application under Newly Reclaimed Sandy Soil. Australian Journal of Basic and Applied Science, 5 1328-1334.

[21] Ulukan, A. (2008) Humic Acid Application into Field Crops Cultivation. Kahraman Maras Sutra Imen University. Journal of Science, 11, 119-128.

[22] Chan, K.Y., Van Zwieten, L., Meszaros, I., Downie, A. and Joseph, S. (2007) Agronomic Values of Greenwaste Biochar as a Soil Amendment. Soil Research, 45, 629-634. http://dx.doi.org/10.1071/SR07109

[23] Yamato, M., Okimori, Y., Wibowo, I.F., Anshori, S. and Ogawa, M. (2006) Effects of the Application of Charred Bark of Acacia Mangiumon the Yield of Maize, Cowpea and Peanut, and Soil Chemical Properties in South Sumatra, Indonesia. Soil Science and Plant Nutrition, 52, 489-495. http://dx.doi.org/10.1111/j.1747-0765.2006.00065.X

[24] Kimetu, J.M., Lehmann, J., Ngoze, S.O., Mugendi, D.N., Kinyangi, J.M., Riha, S., Verchot, L., Recha, J.W. and Pell, A.N. (2008) Reversibility of Soil Productivity Decline with Organic Matter of Differing Quality along a Degradation Gradient. Ecosystems, 11, 726-739. http://dx.doi.org/10.1007/s10021-008-9154-z 
Scientific Research Publishing (SCIRP) is one of the largest Open Access journal publishers. It is currently publishing more than 200 open access, online, peer-reviewed journals covering a wide range of academic disciplines. SCIRP serves the worldwide academic communities and contributes to the progress and application of science with its publication.

Other selected journals from SCIRP are listed as below. Submit your manuscript to us via either submit@scirp.org or Online Submission Portal.
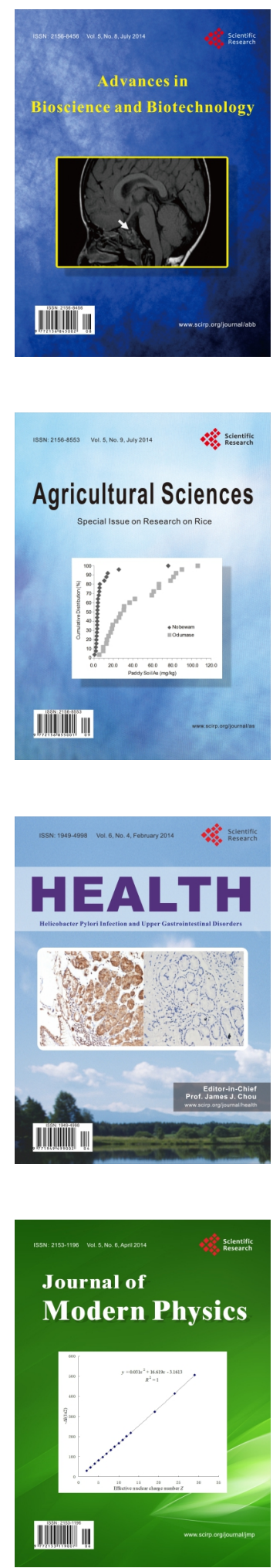
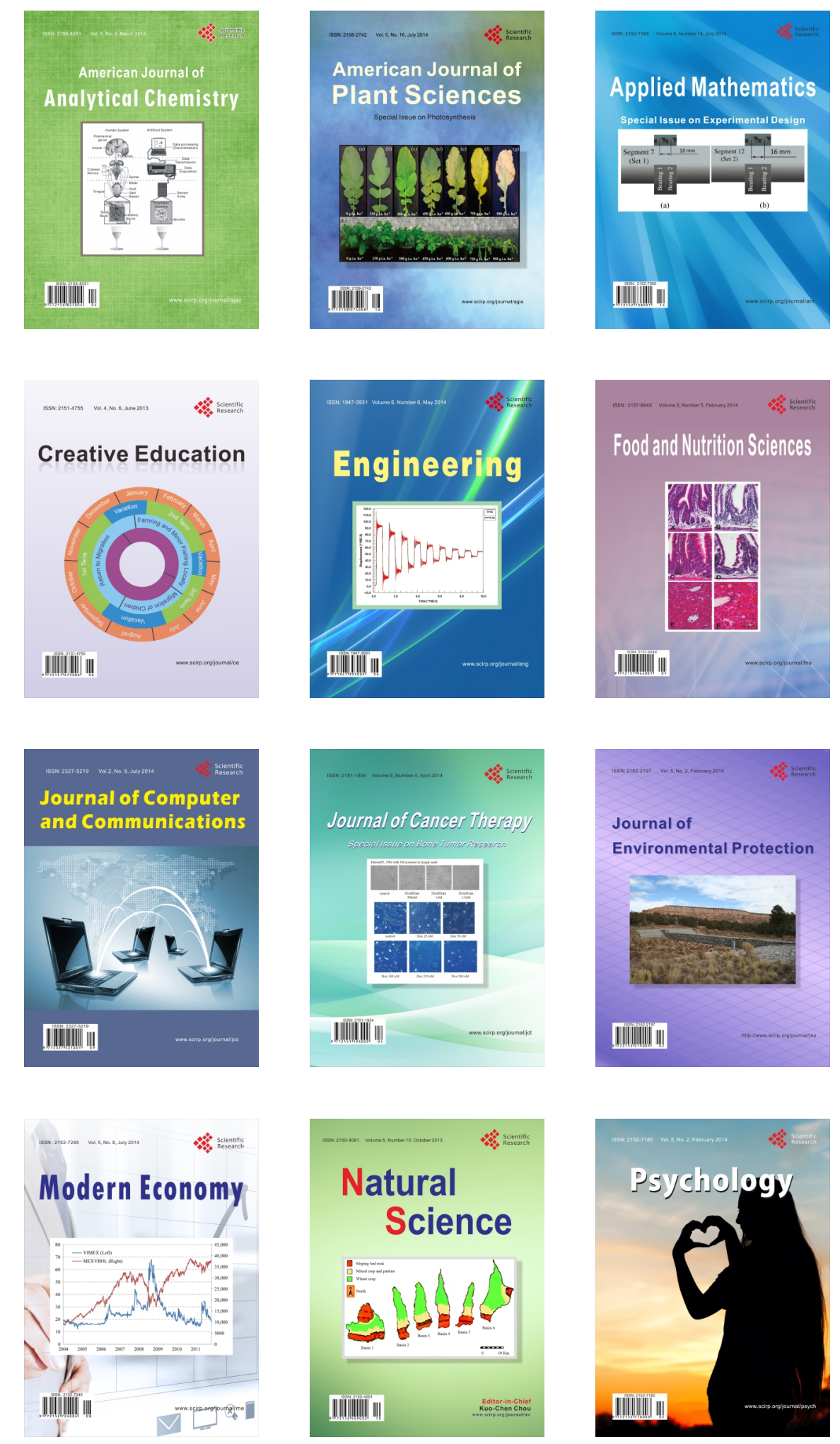